\title{
INLAND ICE-SHEET THINNING NEAR DOME C, EAST ANTARCTICA, CAUSED BY POST-WISCONSINAN
}

\author{
SEA-LEVEL RISE
}

\author{
(Abstract)
}

\author{
by \\ Richard B. Alley* and lan M. Whillans \\ (Department of Geology and Mineralogy and Institute of Polar Studies, \\ Ohio State University, Columbus, Ohio 43210, U.S.A.)
}

A rise of sea-level causes a wave of thinning to move upglacier on an ice sheet ending in the sea, but near-coastal perturbations must be large to affect inland regions significantly. The ice divide at Dome $C$, East Antarctica, is calculated to have thinned by $110 \mathrm{~m}$ owing to the post-Wisconsinan rise of sea-level but thinning has been only $75 \mathrm{~m}$ if the accumulation rate increased by $10 \%$ from Wisconsinan to modern values.

These results are obtained using an ice-flow model that explicitly includes longitudinal-deviatoric stresses. We assume two-dimensional power-law creep over a horizontal bed, and take the flow-law parameter and longitudinal-deviatoric stress to be weighted averages over depth. The flow-law equations for long1tudinal and shear deformation with exponent equal to 3 are then averaged over thickness by integrating explicitly. The two resulting equations, plus the continuity equation and a bottom-sliding relation, describe nonsteady glacial flow. If the bottomsliding relation is correctly specified, this model is applicable to all grounded ice.

To model response of the East Antarctic ice sheet to a post-Wisconsinan rise of sea-level, a Wisconsinan-maximum ice sheet is generated with the Vialov (1958) profile extending to the edge of the continental shelf. Bottom sliding is assumed to be negligible. Values of the flow-law parameter are chosen so that the Wisconsinan-maximum ice sheet is in steady-state with the accumulation-rate distribution selected. Modern accumulation rate is determined from Bull (1971); Wisconsinan-maximum accumulation rate is taken to be some percentage of the modern value. The model is driven by specified thinning near the present coast from Wiscons inan-maximum to modern thickness, occurring at the same time as sea-level rise; this simulates ice-sheet response to sea-level rise and associated isostatic adjustment. This is a fair representation because sea-level rise causes grounding-line retreat and near-coastal thinning with little time delay (Thomas and Bentley 1978).
Model results show that a rise of sea-level causes a wave of thinning to propagate upglacier on an ice sheet in which the terminal position is controlled by sea-level. The wave of thinning is strongly slowed, diffused, and damped as it moves upglacier; thus, perturbations near the coast must be large and have long periods to affect inland regions. Perturbations caused by processes not modeled here, such as delayed isostatic adjustment or small-scale oscillations in sea-level, are smaller and have shorter periods than the perturbation caused by the major post-Wisconsinan sea-level rise; thus, modeling these processes would not alter total calculated thinning in inland regions significantly. Longitudinal stresses are found to be relatively unimportant to the nonsteady response of the East Antarctic ice sheet, but may prove to be important in regions such as ice streams.

For linear thinning near the modern Sabrina Coast $\left(67^{\circ} 00^{\prime} \mathrm{S} 119^{\circ} 30^{\prime} \mathrm{E}\right)$ from the Wiscons inan-maximum thickness to the modern thickness caused by sea-level rise between 15 and $5 \mathrm{ka}$ BP (Milliman and Emery 1968) we calculate that the ice sheet near Dome $C$, East Antarctica, has thinned by $110 \mathrm{~m}$, and that the response is now $70 \%$ complete. A sensitivity study shows that, for values chosen with in reasonable limits, this result is almost independent of assumed flow1 ine length for the Wisconsinan-maximum ice sheet and of timing of sea-level rise. The result is also almost independent of reasonable variations in the flow-law parameter, such as would be required if the Wisconsinan-maximum ice sheet were not initially in steady-state.

Accumulation rate probably changed at the close of the Wisconsinan, and calculated values of total thinning are sensitive to assumed accumulation rate. Total post-Wisconsinan thinning at Dome $C$ owing to the combined effects of sea-level rise and of a step change in accumulation rate taking place $15 \mathrm{ka} B P$ are shown in Figure 1, along with various estimates of the change in accumulation rate. The effect after *Present address: Geophysical and Polar Research Center, University of Wiscons in-Madison, 1215 W Dayton Street,
Madison, Wiscons in 53706, USA. 
$15 \mathrm{ka}$ of change in accumulation rate is only $90 \%$ of that predicted by Whillans (1981) because in this model the position of the outer edge of the ice sheet is controlled and this limits elevation changes of the ice sheet. For a $10 \%$ increase in accumulation

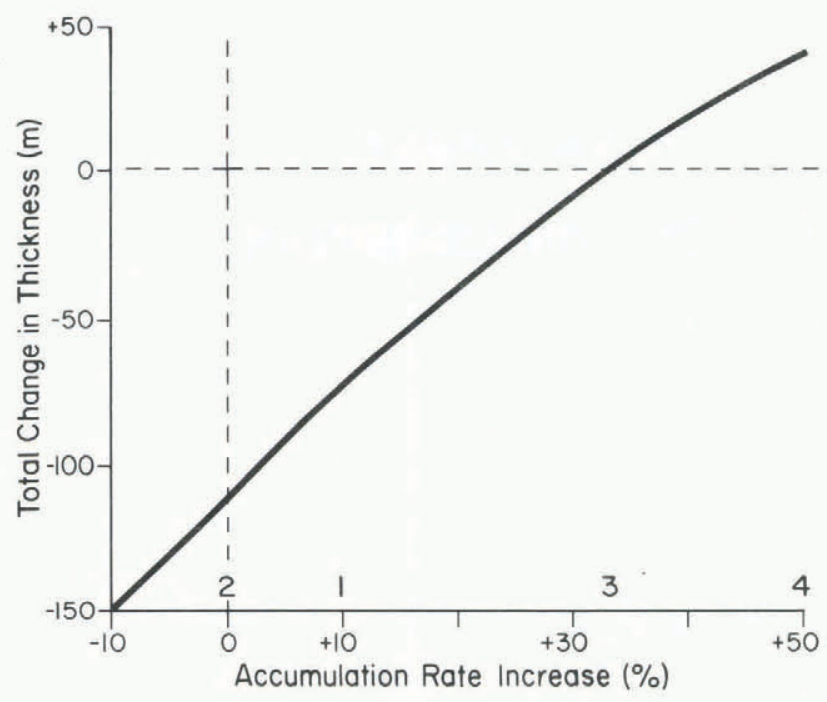

Fig.1. Total thickness change at Dome $C$ over the last $15 \mathrm{ka}$ owing to sea-level rise and to a step increase in accumulation rate $15 \mathrm{ka}$ BP. Approximate percentage increases in accumulation rate from Wiscons inan-maximum to modern values are: (1) about $10 \%$ increase calculated by John Bolzan (personal communication 1983), (2) 1ittle change in accumulation rate, based on microparticle data of Thompson and others (1981), (3) 33\% increase (Lorius and others 1984), (4) $50 \%$ increase (Rob in 1977). rate from Wisconsinan to Holocene values, the ice sheet at Dome $C$ has thinned by $110 \mathrm{~m}$ owing to postWisconsinan rise in sea-level and has thickened by approximately $35 \mathrm{~m}$ owing to post-Wisconsinan increase in accumulation rate, resulting in a total thinning of about $75 \mathrm{~m}$ over the last $15 \mathrm{ka}$.

\section{REFERENCES}

Bul1 C B B 1971 Snow accumulation in Antarctica. In Quam L 0 (ed) Research in the Antarctic. A symposium presented at the Dallas meeting of the American Association for the Advancement of Science - December 1968. Washington, DC, American Association for the Advancement of Science: $367-421$

Lorius C, Raynaud D, Petit J-R, Jouzel J, Merl ivat L 1984 Late-glacial maximum Holocene atmospheric and ice-thickness changes from Antarctic ice-core studies. Annals of Glaciology 5: 88-94

Milliman J D Emery KO 1968 Sea levels during the past 35,000 years. Science 162(3858): $1121-1123$

Robin G de Q 1977 Ice cores and cl imatic change. Philosophical Transactions of the Royal Society of London Ser B 208(972): 143-168

Thomas R H, Bentley C R 1978 A model for Holocene retreat of the West Antarctic ice sheet. Quatermary Research 10(2): 150-170

Thompson L G, Mosley-Thompson E, Petit J-R 1981 Glaciological interpretation of microparticle concentrations from the French 905-m Dome C, Antarctica core. Intemational Association of Hydrological Sciences Publication 131 (Symposium at Canberra 1979 Sea Level, Ice and Climatic Change): 227-234

Vialov S S 1958 Regularities of glacial shields movement and the theory of plastic viscous flow. Inter national Association of Scientific Hydrology Publication 47 (Symposium of Chamonix - Physics of the Motion of Ice): 266-275

Whillans I M 1981 Reaction of the accumulation zone portions of glaciers to climatic change. Jourmal of Geophysical Research 86(C5): 4274-4282

\section{ON LONG-PERIOD INTERNAL OSCILLATIONS IN A SIMPLE}

\section{CLIMATE MODEL WITH AN ICE SHEET}

\section{(Abstract)}

by

\section{G. E. Birchfield}

(Department of Geological Sciences and Department of Engineering Sciences and Applied Mathematics, Northwestern University, Evanston, Illinois 60201, U.S.A.)

$$
\text { and }
$$

\section{J. Weertman}

(Department of Geological Sciences and Department of Materials Science and Engineering, Northwestern University, Evanston, Illinois 60201, U.S.A.)

We review numerical modeling studies of longperiod oscillations which are inherent in ice-sheet physics. Such studies are relevant to the $100 \mathrm{ka}$ component found in proxy ice volume time series. We show that earlier results which were suggestive of lowfrequency oscillations now appear to be an artifact of nonlinear numerical instabilities in the models.
Some specific sources of such numerical instabilities arising from the integration of the highly nonlinear equations in ice sheet models are mentioned. At present, the best numerical ice sheet/climate model does not appear to display a tendency to low frequency selfsustained oscillations. 